\title{
A Menstruating Taboo is Structuring and Shaping the Human Behavior in the Harvesting of Medicinal Plants in a Semiarid Landscape in Brazil
}

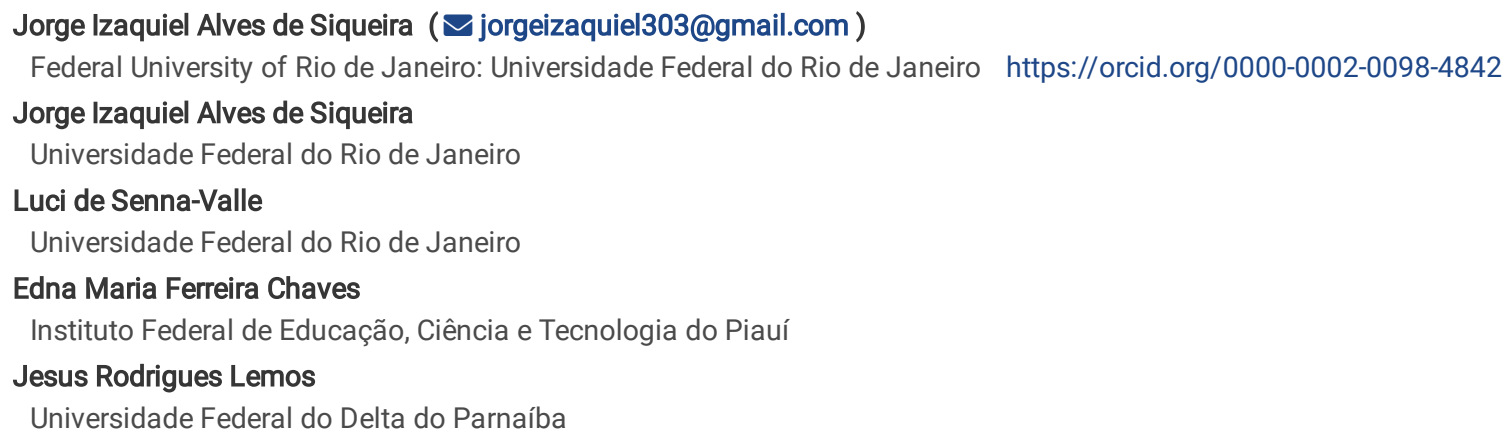




\section{Abstract}

\section{Background}

This article presents, from a biocultural perspective, a menstruating taboo related to the touching, harvesting and preparation of home remedies based on the use of medicinal plants in a rural community located in a semiarid landscape of Cocal municipality, Piauí state, Northeastern Brazil.

\section{Methods}

Methods used include participant observation and semi-structured interviews performed with 27 local people ( 21 female and six male) that recognized a taboo regarding the menstruating cycle and the harvesting of medicinal plants in Franco rural community, Cocal, Piauí, Northeastern Brazil. Semistructured interviews were used to document data regarding the profile of research participants, their perceptions about the taboo documented, as well as the social and biocultural implications of the execution of this traditional practice of prohibition. Participant observation was conducted in order to grasp a better understanding of the social and biocultural implications of the taboo. Additionally, a photographic record was kept during this stage.

\section{Results}

It was verified in Franco rural community that female adolescents and/or women in their menstruating period were prohibited from touching, harvesting and/or preparing home remedies based on the use of medicinal plants. Research participants believed that this can cause the death of medicinal plants, or that they lose their medicinal properties. This taboo has serious social and biocultural implications locally, and can be structured firstly as maladaptive of cultural information at the individual level, as it inhibits the ability of menstruating women to take care of themselves and the health of their families, and secondly as an adaptative strategy at the group level among its users (promotes the transmission of knowledge and cooperation among its users). This traditional practice has serious positive implications for maintaining local bioculturality, sustainability of local medical systems and women's health.

\section{Conclusion}

This taboo documented within the Franco community is an important informal institution with great influence on human biocultural behavior. The inclusion of these perspectives on taboos in biocultural studies offers opportunities for a greater understanding of biocultural attitudes related to interactions between the human species/biota and the environment in a complex knowledge system.

\section{Introduction}

The Brazilian semiarid landscape region occupies about $12 \%$ of the national territory $\left(1.03\right.$ million $\left.\mathrm{km}^{2}\right)$ and 1.262 Brazilian municipalities are located within this area [1]. Caatinga vegetation predominates in this area [2]. The Caatinga, considered one of the main national biomes, is distributed over wide semiarid areas in Northeastern Brazil [3, 4]. The word Caatinga refers to a large geographic area (Biome), comprising different types of vegetation under a dry tropical climate. This area is considered as one of the most populous and diverse semiarid regions on the planet [5].

The Caatinga plays an important role for many local communities associated to subsistence and additional needs [6] (Albuquerque et al. 2017a). In fact, animals and plants from the Caatinga provide various resources to humans, such as food, home remedies, timber, and ornamental species, among other uses [4].

The interrelationships between people, biota, and environment that can occur in this ecosystem are easily observed and/or studied based on human behavior and/or attitudes, emotions, meanings, and cosmovisions, expressed in a wide range of contexts and situations, such as the use of medicinal plants to prevent, treat and/or cure human diseases.

This behavior is considered biocultural, the product of the interactions between genes and culture in a complex and dynamic system. Thus, not only are genes responsible for the behavior in the human species, but culture plays a strong role in the mechanisms that operate, modulate and/or determine these attitudes [7].

From the perspective of understanding the interrelationships between people, biota, and environment, the investigations focused on the interrelationships between human species and plants stand out and are studied by ethnobotany [8]. Among the complex and different variables that can affect local knowledge regarding the use of plants by local people, gender, level of schooling, income, age, prestige and/or social status, the ways and/or processes of social/cultural transmission and the environmental perception are listed among many other important variables [9].

Despite this extensive list, other factors such as the presence and spread of taboos also have a strong influence on the modulation and determination of local people/plants interrelationships. "Taboos represent unwritten social rules that regulate human behavior" [10, p. 1]. These restrictions and/or prohibitions can affect not only human social life, but also elements of the local natural environment [10] and, as a result, human biocultural behavior.

In this way, taboos are seen as informal institutions that can offer advantages in biodiversity conservation projects, involving mutual cooperation between conservationists and local communities $[11,12,13,14]$. Thus, taboos have important socioecological functions that are structured based on symbolism and spirituality, history and politics, and economic and environmental conditions [15], among other biocultural aspects inherent to humans.

Despite their importance, taboos are strongly neglected by developing countries rich in biodiversity in the design of conservation projects [16] Furthermore, the use of taboos as a model for understanding human behavior related to the use of medicinal plants is incipient in ethnobiological

Page $2 / 18$ 
research conducted around the world, being more concentrated in the food use category, important for the conservation of biological and cultural diversity [see $14,17,18]$.

In many cultures, taboos related to the use and exploitation of natural resources are present and are widely disseminated among the members of the society. These taboos can become fixed and act as biocultural traits and/or maladaptive cultural information. Information considered to be maladaptive does not contribute positively to the biological and cultural fitness of human populations, but it remains fixed to them [19]. An interesting example of maladaptive cultural information is the use of a medicinal plant in a certain community and/or social/cultural context, but that has no biological efficacy, and therefore does not treat the target disease [20]. Despite this, structuring taboos can be considered an adaptation strategy, with great ecological importance [13].

Building on the findings that taboos are important for the understanding of human biocultural behavior, this study explores the social and biocultural relationship between a taboo related to the prohibition of female adolescents and/or women in their menstrual cycle from the touching, collecting, and preparing of home remedies based on the use of medicinal plants in a rural community in the semiarid region of Piauí state, Northeastern Brazil.

\section{Materials And Methods Characterization of the study area}

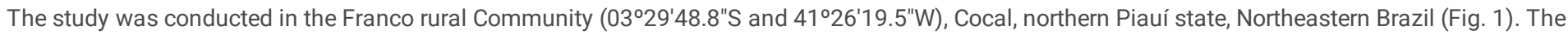
municipality is $268 \mathrm{~km}$ from the capital state, Teresina. It has a population of 26.036 inhabitants and a demographic density of 20.51 inhabit./km ${ }^{2}$ [21] (IBGE, 2010). The community's territorial area is within the limits of the Environmental Protection Area-EPA of Serra da Ibiapaba [22], an important area with great biocultural significance for the people who live there or in its surroundings.

Locally, there are two well-characterized and/or defined seasons, which include: (1) rainy summer, in which the tropical dry forest, in general terms, is dense with green cover and many herbaceous plants, sub-shrubs and seasonal shrubs and, (2) warm winter, the period of the year when seasonal plants tend to disappear and other perennial plants, in general, lose their leaves. The region's climate is classified as Hot Tropical, with $25^{\circ} \mathrm{C}$ and $35^{\circ} \mathrm{C}$ as the maximum and minimum temperatures, respectively. It has an annual rainfall range of $900 \mathrm{~mm}$; the highest indices are registered over the months of March/May, while the lowest values are related to the months of July and August [23, 24].

In Cocal municipality, the vegetation is characterized as Carrasco, it is widely distributed throughout the municipality, which is characterized by its deciduous, dense shrub plants and dense physiognomy, with predominance species of the families Fabaceae, Euphorbiaceae, Bignoniaceae, Rubiaceae, and Asteraceae $[25,26]$. The Carrasco plants represent an important source of resources for the rural populations of Cocal, offering several ecosystem services, such as food, medicines, forage, timber, and fuel, among other important uses for local livelihoods [25, 26, 27, 28, 29, 30].

In the Franco rural community, there are several biocultural landscapes and/or landscape mosaics resulting from human activities [31], such as agriculture, firewood collection, traditional charcoal production, and animal husbandry, among others.

The Franco community is a small village with rural characteristics and ways of life. Local residents $(n=115)$ live on subsistence farming and raising animals, such as chickens, sheep, pigs, goats, and cattle. Few people $(n=4)$ also supplement their income by dedicating themselves to small local commerce, commonly known as 'quitandas' and/or 'bodegas,' where they sell a variety of food products, beverages, and general items. Many local residents also sell their surplus crop production at the free fair of Cocal city. In past times, fishing and hunting activities were common practices, especially among male members of this community. Currently, they carry out these practices sporadically.

One of the most important characteristics that represents the way of life of the Franco rural community is the presence of homegardens, spaces around and/or close to homes where a high diversity of plant species are cultivated, especially for food and medicinal purposes [29, 31, 32]. These spaces, the homegardens, are important landscapes of biocultural significance for the Franco rural community [32].

There are no schools in the community, nor are there units for medical assistance. Residents attend schools in other nearby rural areas or even move to the urban area of Cocal. The same situation applies for medical assistance, which can occur in other rural communities or in the urban area of the municipality of Cocal. When in serious, urgent, and/or specific health cases, and if there is no adequate condition for assistance at the headquarters of the municipality, patients are transferred to Parnaíba, a municipality that is also part of the Piaui coast and is $92.3 \mathrm{~km}$ away from Cocal. Locally, there are two health agents, each of them works in a specific local geographic area, but residents mention that their jobs are not so active and that care for the health of the locals is often neglected. In the community, there is a Catholic Church; four local people are evangelicals and lead another community to attend religious cults (some landscapes and routines commonly observed in the Franco rural community can be seen in Figures 2-3).

\section{Ethical and legal procedures}

The research proposal was submitted and approved (process number 2.165.239) by the Research Ethics Committee-CEP of the Federal University of Piauí-UFPI, Campus Ministro Reis Velloso-CMRV. To carry out the stages of the ethnobotanical fieldwork, visits and meetings were conducted with local residents, making data related to the research clear, such as methods of data collection, objectives, importance, benefits, and risks, among others [33]. 
For each research participant, the Informed Consent Registration Document (ICRD) was read, discussed, and clarified [34]. After the agreement, as required by protocol, the document was signed by each participant. For the photographic registration of local residents collecting plants and/or performing some daily activity, the Term for Use of Image-TUI was applied, allowing its reproduction and use only for scientific and divulgation purposes [35]. When the local people appearing in the photographs were under 18 years of age, the Term of Consent for Use of Image-TAUI was used, signed by both the responsible person(s) and/or parents, as well as by the subject themselves.

\section{Theoretical approach and data collection methods}

The ethnobotanical investigation was structured as descriptive qualitative research This type of research has as its basic characteristic the collection of descriptive data, in which it seeks to understanding the meanings attributed to contexts [36].

In this way, in order to select the research participants, to know their socioeconomic profile and to document data on a taboo related to menstruation and the collection and use of medicinal plants, the first author conducted the ethnobotanical fieldwork from August 2017 to May 2018 , which has been guided by the following protocol:

(a) He carried out visits and informal conversations with local people [37]. The non-probability sampling design known as 'snowball' was applied to select research participants [38];

(b) He conducted semi-structured interviews [36], which were used to establish the socioeconomic profile of research participants, describe and document the social and biocultural implications related to a local taboo associated with menstruation. People were interviewed preferentially individually, in order to avoid interferences by other parties in their responses [39]; both women and men were interviewed because they have recognized the taboo and both genders offer a greater understanding of it;

(c) He performed the participant observation technique [40]. During this stage, local people's behavior was recorded when dealing with the topic of menstruation and the collection and use of medicinal plants. In addition, local residents were accompanied to the forests and/or homegardens during plant harvesting events and/or parts of them. All this information was recorded in writing in a field journal [41];

(d) He registered photographs of areas of the community, places of medicinal plant cultivation, and events guided by local people for harvesting medicinal plants in the forests or homegardens of the region.

\section{Results}

\section{Characterization of research participants}

Twenty-seven local residents participated as subjects of the research; 21 and six belonging to the female and male genders, respectively. They are characterized by low levels of schooling and few economic resources (Table 1). In general, they are farmers and have a frequent custom both of growing in homegardens and of collecting medicinal plants in the forests. The use of medicinal plants is part of the routine of health care in the Franco rural community [see 29].

Table 1

Socioeconomic data of the research participants interviewed in the Franco rural community, Cocal, Piauí, Northeastern Brazil. 


\begin{tabular}{|c|c|c|c|}
\hline Variables & Cases & Frequency & $\%$ \\
\hline \multirow[t]{2}{*}{ Gender } & Female & 21 & 77.78 \\
\hline & Male & 6 & 22.22 \\
\hline \multirow[t]{6}{*}{ Age } & 20 to 30 years old & 3 & 11.11 \\
\hline & 31 to 40 years old & 7 & 25.93 \\
\hline & 41 to 50 years old & 5 & 18.52 \\
\hline & 51 to 60 years old & 3 & 11.11 \\
\hline & 61 to 70 years old & 5 & 18.52 \\
\hline & More than 70 years old & 4 & 14.81 \\
\hline \multirow[t]{4}{*}{ Marital status } & Married/Free union & 16 & 59.26 \\
\hline & Divorced & 3 & 11.11 \\
\hline & Widower & 3 & 11.11 \\
\hline & Single & 5 & 18.52 \\
\hline \multirow[t]{6}{*}{ Schooling level } & Illiterate & 16 & 59.26 \\
\hline & Literate & 3 & 11.11 \\
\hline & Incomplete Primary School & 4 & 14.81 \\
\hline & Complete Primary School & 2 & 7.40 \\
\hline & Incomplete High School & 1 & 3.71 \\
\hline & Complete High School & 1 & 3.71 \\
\hline \multirow[t]{3}{*}{ Monthly income } & Without income & 10 & 37.04 \\
\hline & $<$ A minimum wage & 8 & 29.63 \\
\hline & A minimum wage & 9 & 33.33 \\
\hline
\end{tabular}

\section{Description of the traditional taboo associated with the harvesting of medicinal plants by local people}

In the Franco rural community, there is an ingrained practice associated with the menstrual period and the harvesting and/or preparation of home remedies based on the use of medicinal plants (some of the medicinal plant species commonly used locally and local people harvesting these natural resources can be seen in Figures 4-7). This applies to both the wild species collected in the forests and the species that have been traditionally cultivated and/or maintained in the homegardens. Locally, female adolescents and/or women in their menstrual cycles are prohibited from touching, harvesting and/or preparing home remedies from medicinal plants. This taboo is recognized by both men and women of this community.

This practice is strongly disseminated locally and is structured and supported among research participants based on the following statements: (1) female adolescents and/or women in their menstrual periods who touch, collect and/or perform preparations using medicinal plants would cause negative effects on the plant species, influencing the death of the plant individual(s) due to this interaction, applying to both species in the forests and plants cultivated in homegardens, and; (2) female adolescents and/or women during the menstrual period who touch, collect and/or prepare home remedies with medicinal plants would be contributing to these resources losing their medicinal and/or bioactive properties, having no effect on the use of home remedies in the therapeutic target and/or illness. As a consequence, their time and energy are being used without positive results for the restoration of health, according to the perception of local people during the interviews.

\section{Implications of the taboo related to the menstruation and harvesting of medicinal plants}

The condition of menstruating in the Franco rural community implies a total prohibition on touching, harvesting and preparing home remedies based on the use of medicinal plants. According to the perception of research participants, when a female adolescent and/or woman collects plants cultivated in raised plant bed (present in homegardens), all the plant species present there die (both food and medicinal), making manure (organically fertilizer) unusable, requiring a complete replacement. However, in cases where these women are sick, they can administer home remedies prepared by people of the male gender of this community, or even prepared by non-menstruating females. 
This taboo around menstruation remains very strong among the research participants, and its violation can have serious implications among members of the community, such as social isolation (intra-community) and even physical aggression (intra-family). However, $7.40 \%$ ( $n=2$ ) of the research participants reported that they violated this taboo in emergency situations regarding the use of medicinal plants, even though they mention that the other individuals cannot discover such a violation. These emergencies are associated with illness events and the lack of availability of another person to prepare home remedies, or another alternative cure, such as drugs from allopathic medicine, among others. In figure 8, we present a figure representing the biocultural behavior for men and women interviewed when this taboo described is established.

\section{Discussion}

\section{Description of the traditional taboo associated with the harvesting of medicinal plants by local people}

In the past, the taboo described related to menstruation and the touching, collection and preparation of home remedies based on the use of medicinal plants in the Franco rural community may have been important for local adaptative values, helping to preserve women's fertility. According to research participants' perceptions, hygiene and body care conditions when the local women were menstruating were very different from current conditions, there were no sanitary pads and/or many personal hygiene products in the past.

Initially, at individual level, this taboo is structured as a trait and/or maladaptive cultural information in the local culture. Traits with these characteristics are behaviors that apparently do not contribute positively to the biological and/or cultural fitness of a population. In the Franco rural community, women are attributed the role of "caregivers" or "caretakers". It is a social construction, and in many ways, it can show patriarchal biases [44]. Therefore, when someone in the family is sick in this community, the woman is the first to act and seek an available cure strategy, generally based on the use of medicinal plants [29].

Family health is strongly dependent on the role played by women. The structuring of this taboo around menstruating women decreases their ability to care for others and their own health, establishing a maladaptive behavior. This constitutes a risk scenario if we consider the past environment of the community and the configuration of the local medical system some decades ago, in which local people, most of the time, used medicinal plants to treat their illnesses. Allopathic medicine was inexistent and inaccessible due to low economic resources in this region.

In addition, this taboo is strongly linked to the association of two pieces of information that do not have any causal relationship and/or dependence, as is often the case with cultural traits linked to superstitions [45]. Thus, the circumstance of superstition is associated with the learning of observation of coincidence (associative learning) [46]. The phenomenon that menstruating women touch, collect and prepare home remedies from the use of medicinal plants does not imply that these plants lose their effectiveness and/or die. Plants do not discriminate between who is and who is not menstruating [47].

When asked about the origin of the taboo, the research participants (both men and women) reported that they do not precisely know its origin, only that it comes from older people, from past generations, although it is associated with religious customs and local perceptions regarding menstruation.

According to their local perception, when a woman is menstruating her body is completely open, a situation that can allow bad energy to enter. In these contexts, the contact with plants can transfers these energies from the woman's body to the plant.

Based on these ideas, our hypothesis is that this taboo has a strong relationship with the origin of superstitions in general. In past times, in stressful environments and totally different from today's biocultural landscapes, it may be that some menstruating woman has witnessed the death of plants after an interaction, touching and collecting these medicinal resources, or that she has prepared a home remedy based on the use of medicinal plants during menstrual periods, and it has not been effective on the therapeutic target.

Subsequently, she, her husband or someone in the family circle has made the association between menstruating and the observed consequence (e.g., the plants die and/or the medicine was not effective). Our suggestions described are supported by the idea presented by Abbott \& Sherratt (2011, [45]) associated with superstitions, that "if an outcome occurs after performing an action, then this might suggest to the agent that the action increases the probability that the outcome occurs" [45, p. 85-6].

In fact, the understanding of taboos in human societies is complex, as they may have ecological, social, religious origins and show variation according to the function of each taboo $[11,13]$. In Franco rural community, the herein described practice of prohibition has a strong relationship with religious and social customs, perceptions of menstruation, and patriarchal biases. The last issue needs to be further investigated in future research on bioculturality and menstruating taboos.

In view of this scenario, our purpose here is not to scientifically validate or seek scientific bases for this taboo but to treat it as an informal institution that can determine the human behavior related to the touching, harvesting, and preparing of home remedies from medicinal plants.

This taboo is considered a maladaptive behavior at the individual level, but this situation is reversed when considering its benefits at group level. It has serious implications for maintaining local bioculturality, sustainability of local medical systems, and women's health. In the next subtopic, we discuss these implications and the role of the menstruating taboo described as an adaptive behavior at group level.

\section{Implications of the taboo related to menstruation and harvesting of medicinal plants}


The taboo described for the Franco rural community has serious local implications. Remarking it, according to the perception of research participants, as a cause of touching, harvesting, and preparation of home remedies by women in the menstrual period, plants tend to die and/or lose their bioactive properties. Additionally, it makes the manure where the species are growing unusable.

Despite being widely disseminated among research participants and recognized by both men and women, two female participants reported having violated this taboo in emergency situations. This represents $9.52 \%$ of the overall total of women interviewed. In this aspect, when the people deviate from a taboo, or when they consider such a deviation, they indirectly weaken the taboo. The strength of a taboo is a discrete function of the percentage of individuals who violate it [48]. Thus, this taboo has great strength and acceptance among research participants in the Franco rural community. Breaking this taboo can have social costs and its users prefer not to incur them.

The attitude of not violating the local taboo is of great importance among users. This situation favors trust between local people, strengthens the feeling of group. People tend to follow behaviors that are followed by their peers and/or similar.

Menstrual taboos are present in many cultures around the world. For exampling it, in South Africa and Swaziland, menstruating women are prohibited from collecting medicinal plants. They believed that this would avoid reducing the plant medicine's healing power [49]; this traditional prohibition is similar to the taboo described in the Franco rural community. However, this taboo on the African continent regulates the traditional use of medicinal species locally, reducing the anthropogenic pressure on these plant species [see 49].

In the Franco rural community, this taboo does not necessarily lessen the anthropogenic pressure on medicinal plant species, because men and women who are not menstruating can collect plants when menstruating women are prohibited from doing this activity. Despite this, it can decrease the pressure on vegetal species, when women use another cure option available, such as allopathic medicine, animal products, prayers and blessings, among several others.

The reported taboo, although apparently presenting only negative consequences in violation events (such as social isolation, physical aggression and disagreements, and others), also assumes positive characteristics and/or traits. The contribution in increasing the interaction between humans and the plant resources of this community is clear, expressed in biocultural attitudes and/or behaviors by both men and women living in this area. Although in this community the role of the female gender stood out in the collection and preparation of home remedies based on the use of medicinal plants [29, 31 , 32], the men play an important role when women and/or adolescents are in menstruating period.

In the Franco rural community, it has been reported that in this period of menstruation, men can collect plants in the forests, homegardens and prepare home remedies. This scenario contributes to the maintenance of bioculturality associated with the use of medicinal plants locally. Women who are not menstruating, when in situations of need and/or urgency, can also collect and prepare home remedies for women who are following the practice of prohibition.

Young adults belonging to the male gender of this community know several harvesting techniques, medicinal plant species, and methods of preparing various home remedies, as well as the therapeutic targets and other cosmovisions involved (see Fig. 7 again). During the collection, these young people usually never go alone to the forests, mostly carrying out this activity accompanied by local children and/or adolescents, helping them to also learn the practices associated with this biocultural information.

From these scenarios described above, the structuring and establishing of the taboo promotes processes of knowledge transmission, contributing to the conservation of biological and cultural diversity [50]. In this context, from a group level perspective, it is structured as an adaptive behavior, increasing survival and cooperation among its users. As pointed out by Boyd \& Richerson (2009, [7]), cooperation was a key element in human evolution, with culture also playing a significant role. Social cooperation is motivated by several factors, such as the possibility of suffering social costs and losing several benefits at group level, such as mutual help when someone is sick [7].

The behavior of helping others creates conditions for reciprocal help in the future, especially in events of illness. This assumption establishes complex relations of reciprocity in humans [see 51]. People who help others get a good reputation and are more likely to be helped by other individuals in the social group in the future [52].

Many times, women who are menstruating when sick are faced with complex scenarios that require quick decision making, which include: (1) lack of availability of a non-menstruating female who can prepare a home remedy based on the use of medicinal plants; (2) lack of availability of a male person who can collaborate with the harvesting and execution of medicinal preparations based on the use of plants; (3) the opportunity to violate (uncommon and risky) a practice widespread in the community, collecting the plant(s) and preparing the medicine despite menstruating and; (4) choose another alternative for the treatment and/or cure of the disease.

In the latter case, they would choose an alternative cure/treatment of diseases that did not involve the harvesting and preparation of medicines from medicinal plants. Locally, several hybrid knowledge systems coexist, governed by complementary and/or alternative configurations [31]. Among these options, there would be the use of allopathic medicinal remedies, prayers (local specialists in healing), use of products and/or parts of wild and domesticated animals, human products, and minerals, among others. As reported by Ladio and Albuquerque (2014 [53]) these systems can coexist in the same space, not necessarily representing processes of homogenization and/or the mixing of these knowledge systems. The structuring of hybridization can follow adaptive patterns [54], which is very important for the sustainability of local medical systems. 
In addition, according to the research participants' perceptions, this taboo is configured as a means of protecting the health of individuals and/or medicinal plants in homegardens and forests. The attitude of administering medicine from a plant prepared by a woman during menstruation, having the belief that, due to this situation the plant would lose its bioactive properties, would be like being faced with a complex situation that involves the urgency for the cure of a human illness, added to the circumstances of wasted time and energy employed in this phenomenon.

Thus, studies involving the perception of health/diseases and taboos as events that modulate human behavior associated with the harvesting and use of medicinal plants are structured as important ways of understanding the dynamics and sustainability of local medical systems. According to Fabrega (1997 [55]), the behavior associated with caring for oneself and for one's peers is of great importance in human evolution, taking into account that disease affects the reproduction and survival of human populations. In addition, it can also affect social relationships in human groups [55], as was evident in the taboo described if violated.

\section{Conclusions}

The taboo described can be interpreted as a maladaptive cultural information at individual level, reducing the ability of menstruating women to take care of their own health and that of their families. At a group level, this practice has been structured as an adaptive behavior, promoting the transmission of knowledge about medicinal plants and cooperation among its users.

The menstruating taboo described plays an important role in modulating and determining human behavior among the research participants interviewed in Franco rural community associated with the touching, harvesting and use of medicinal plants by women in their menstrual period.

The origin of this taboo is complex. It has a strong relationship with religious and social customs, perceptions of menstruation, and patriarchal biases. The inclusion of these perspectives on taboos in biocultural investigations offers opportunities for a greater understanding of biocultural attitudes related to interactions between the human species, biota and the environment in a complex knowledge system.

\section{Declarations}

\section{Acknowledgments}

We would like to extend our most sincere thanks to all the people of the Franco rural community, especially to the 27 local residents who collaborated with this research, for their kindness and sharing of important knowledge. To "Conselho Nacional de Desenvolvimento Científico e Tecnológico-CNPq" (acronyms in Portuguese language) for the scientific scholarship provided to the first author (research project identification $\mathrm{Pl} / 2742-2017$ ). To the UFPI/CMRV for the support and possibility of using its infrastructure, especially of the Botany Laboratory.

\section{Funding}

This research was supported in part by funding (research project identification Pl/2742-2017) from "Conselho Nacional de Desenvolvimento Científico e Tecnológico-CNPq," a Brazilian agency that promotes scientific research and scientific development in the country.

\section{Availability of data and materials}

Not applicable.

\section{Author Contributions}

JIAS conceived the idea and the design of the study, collected data using qualitative methods in the field, wrote the first and final versions of the manuscript. LSV, EMFC, JRL revised and suggested several corrections in the first and final versions of the manuscript. All the authors critically read this article and approved it as the final manuscript.

\section{Ethics approval and consent to participate}

The research proposal was submitted and approved (process number 2.165.239) to the Research Ethics Committee-CEP of the Federal University of PiauíUFPI, Campus Ministro Reis Velloso-CMRV. All participants were asked for their free prior informed consent before interviews were conducted.

\section{Consent for publication}

Consent for publication of this study is granted by the authors Jorge Izaquiel Alves de Siqueira, Luci de Senna-Valle, Edna Maria Ferreira Chaves and Jesus Rodrigues Lemos. All people depicted in photographic in this paper agreed that those images together with their identities could be published. 


\section{Competing interests}

The authors declare that they have no competing interests.

\section{References}

1. Brasil. Resolução n 115, de 23 de Novembro de 2017. Brasília: Diário Oficial da União, SUDENE; 2017.

2. Silva JMC, Leal IR, Tabarelli M. Caatinga: The Largest Tropical Dry Forest Region in South America. Gewerbestrasse: Springer; 2017.

3. Rodal MJN, Sampaio EVSBA. Vegetação do bioma Caatinga. In: Sampaio EVSBA, Giulietti AM, Virginio J, Gamarra-Rojas CFL, editors. Vegetação e flora da Caatinga. Recife: PNE/CNIP, Recife; 2002. p. 11-24.

4. Albuquerque UP, Araújo EL, El-Deir ACA, Lima ALA, Souto A, Bezerra BM, Ferraz EMN, Freire EMX, Sampaio EVSB, Las-Casas FMG, Moura GJB, Pereira GA, Melo JG, Ramos MA, Rodal MJN, Schiel N, Lyra-Neves RM, Alves RRN, Azevedo-Júnior SM, Telino-Júnior WR, Severi W. Caatinga revisited: ecology and conservation of an importante seasonal dry forest. Sci World J. 2012; doi: doi.org/10.1100\%2F2012\%2F205182.

5. Santos MG, Oliveira MT, Figueiredo KV, Falcão HM, Arruda ECP, Almeida-Cortez J, Sampaio EVSB, Ometto JPHB, Menezes RSC, Oliveira AFM, Pompelli MF, Antonino ACD. 2014. Caatinga, the Brazilian dry tropical forest: can it tolerate climate changes? Theor Exp Plant Physiol. 2014; doi: doi.org/10.1007/s40626-014-0008-0.

6. Albuquerque UP, Araújo EL, Castro CC, Alves RRN. People and natural resources in the Caatinga. In: Silva JMC, Leal IR, Tabarelli M, editors. Caatinga; The largest tropical dry forest region in South America. Gewerbestrasse: Springer; 2017. p. 303-333.

7. Richerson PJ, Boyd R. Not by Genes Alone: How Culture Transformed Human Evolution. Chicago: The University of Chicago Press; 2005.

8. Albuquerque UP, Ramos MA, Ferreira-Júnior WS, Medeiros PM. Ethnobotany for Beginners. New York: Springer; 2017.

9. Albuquerque UP, Alves RRN. Introdução à Etnobiologia. 2ª Edição Revisada e Ampliada. Recife: NUPEEA; 2018.

10. Colding J, Folke C. The relations among threatened species, their protection, and taboos. Ecol Soc. 1997;1:6.

11. Colding, J.; Folke, C. Social taboos: "invisible" systems of local resource management and biological conservation. Ecol Appl. 2001; doi: doi.org/10.1890/1051-0761(2001)011[0584:STISOL]2.0.CO;2.

12. Colding J, Folke C, Elmqvist T. Social institutions in ecosystem management and biodiversity conservation. Tropical Ecology. 2003;44:25-41.

13. Negi CS. The institution of taboo and the local resource management and conservation surroundings sacred natural sites in Uttarakhand, Central Himalaya. Int J Biodivers Conserv. 2010;2:186-195.

14. McNamara K, Wood E. Food taboos, helath beliefs, and gender: understanding househol food choice and nutrition in rural Tajikistan. J Ethnobio Ethnomed, 2019; doi: doi.org/10.1186/s41043-019-0170-8.

15. Golden CD, Comaroff J. Effects of social change on wildlife consumption taboos in northeastern Madagascar. Ecol Soc. 2015; doi: doi.org/10.5751/ES-07589-200241.

16. Robbins P. Nomadization in Rajasthan, India: migration, institutions, and economy. Hum Ecol. 1998; doi: doi.org/10.1023/a:1018748917722.

17. Begossi A, Hanazaki N, Ramos RM. Food chain and the reasons for fish food taboos among Amazonian and Atlantic Forest Fishers (Brazil). Ecol Appl. 2004;14:1334-1343.

18. Henrich J, Henrich N. The evolution of cultural adaptations: Fijian food taboos protect against dangerous marine toxin. Proc Biol Sci. 2010;277:37153724.

19. Mesoudi A. Cultural Evolution: how Darwinian theory can explain human culture and synthesize the social sciences. Chicago: Chicago Press; 2011.

20. Dantas JI, Nascimento ALB, Silva TC, Albuquerque UP. 2020. Mutation of cultural information on the use of plant complexes in local medical systems. Evid Based Complement Altern Med. 2020; doi: doi.org/10.1155/2020/7630434.

21. IBGE- Instituto Brasileiro de Geografia e Estatística. Cidades. 2010. https://cidades.ibge.gov.br/. Accessed 01 May 2020.

22. Brasil. Decreto de 26 de novembro de 1996. 1996. http://www.planalto.gov.br/ccivil_03/dnn/anterior\%20a\%202000/1996/dnn4781.htm. Accessed 12 Jan 2020.

23. IBGE. Geografia do Brasil, Região Nordeste. Rio de Janeiro: SERGRAF-IBGE; 1977.

24. Medeiros RM. Estudo agrometeorológico para o estado do Piauí. Teresina: Sema; 2004.

25. Chaves EMF. Florística e potencialidades econômicas da vegetação de carrasco no município de Cocal, Piauí, Brasil. 2005.113 f. Thesis (Master Degree in Environment and Development) —Universidade Federal do Piauí, Teresina; 2005.

26. Chaves EMF, Barros RFM. Diversidade e uso de recursos medicinais do carrasco na APA da Serra da Ibiapaba, Piauí, Nordeste do Brasil. Rev Bras PI Med. 2012; doi: doi.org/10.1590/S1516-05722012000300009.

27. Chaves EMF, Barros RFM. Resource use of the flora of the brushwood vegetation in Cocal country, Piauí, Brazil. Funct Ecosyt Communit. 2009;2:5158.

28. Chaves EMF, Chaves EBF, Sérvio-Júnior EM, Barros RFM. Conhecimento tradicional: a cultura das cercas de madeira no Piauí, Nordeste do Brasil. Etnobiología. 2014;12:31-43.

29. Siqueira JIA, Chaves EMF, Lemos JR. Ethnobotanical Study on The Use Medicinal Plants in Agroforestry Backyards in The Environmental Protection Area of The "Serra da Ibiapaba", Northeastern Brazil. In: Mathias A, Laisné N, editors. Medicinal Plants: Production, Cultivation and Uses. New York:

Page $9 / 18$ 
Nova Science Publishers; 2017. p. 211-230.

30. Chaves EMF, Siqueira JIA, Morais RF, Barros RFM. 2019. Conocimiento y uso de plantas alimenticias silvestres en comunidades campesinas del Semiárido de Piauí, Noreste de Brasil. Ethnobot Res Appl. 2019; doi: doi.org/10.32859/era.18.33.1-20.

31. Siqueira JIA, Machado TJ, Lemos JR. Bioculturalidad asociada a la extracción y uso del aceite de una etnovariedad de Sesamum L. (Pedaliaceae): un abordaje etnobotánico en un pueblo del Semiárido de Piauí (Noreste de Brasil). Ethnobot Res Appl. 2019; doi: doi.org/10.32859/era.18.17.1-26.

32. Siqueira JIA, Vieira IR, Chaves EMF, Sanabria-Diago OL, Lemos JR. Biocultural behaviour and traditional practices on the use of species of Euphorbiaceae in rural home gardens of the Semiarid region of Piauí State (NE, Brazil). Caldasia. 2020; doi: doi.org/10.15446/caldasia.v42n1.76202.

33. Brasil. Conselho Nacional de Saúde, Resolução № 466, de 12 de Dezembro de 2012. Brasília: Diário Oficial da União; 2012.

34. International Society of Ethnobiology-ISE. ISE Code of Ethics (with 2008 additions). 2006. http://ethnobiology.net/code-of-ethics/. Accessed 01 Jun 2020.

35. Brasil. Conselho Nacional de Saúde, Resolução № 510, de 07 de Abril de 2016. Brasília: Diário Oficial da União; 2016.

36. Martin GJ. Ethnobotany: a methods manual. Londres: Chapman and Hall; 1995.

37. Alexiades MN. Protocol for Conducting Ethnobotanical Research in the Tropics. In: Alexiades, MN, editor. Ethnobotanical Research: A Field Manual. New York, USA: The New York Botanical Garden; 1996. p. 5-18.

38. Bailey KD. Methods of social research. New York: Free Press; 1982.

39. Phillips O, Gentry AM. The useful plants of Tambopata, Peru: I. Statistical hypothesis with a new quantitative technique. Econ Bot. 1993; doi: doi.org/10.1007/BF02862203.

40. Bernard HR. Research Methods in Anthropology: Qualitative and Quantitative Approaches. Oxford: Altamira Press; 2006.

41. Falkembach EMF. Diário de campo: um instrumento de reflexão. Rev Cont Educ. 1987;7:19-24.

42. Reflora. Lista de Espécies da Flora do Brasil. 2020 (em construção). http://floradobrasil.jbrj.gov.br/reflora/listaBrasil/PrincipalUC/PrincipalUC.do;jsessionid=A2E43826B2F9AE167FCB36C393648F5\#CondicaoTaxonCP. Accessed 01 May 2020.

43. The Plant List (TPL). TPL: A working list of all plant species. 2013. http://www.theplantlist.org/. Accessed 01 May 2020.

44. Ladio AH. La etnobiología en áreas rurales y su aporte a la lucha para desentrañar sesgos patriarcales. Ethnoscientia. 2020; doi: doi.org/10.22276/ethnoscientia.v5i1.298.

45. Abbott KR, Sherratt TN. The evolution of superstition through optimal use of incomplete information. Animal Behav. 2011; doi: doi.org/10.1016/j.anbehav.2011.04.002.

46. Beck J, Forstmeier W. Superstition and belief as inevitable by-products of an adaptive learning strategy. Hum Nat. 2007; doi: doi.org/10.1007/BF02820845.

47. UNICEF. 2019. Busted. Eight myths about periods. 2019. https://www.unicef.org.au/blog/news-and-insights/september-2019/busted-8-myths-aboutperiods. Accessed 20 Aug 2020.

48. Fershtman C, Gneezy U, Hoffman M. 2011. Taboos and identity: considering the unthinkable. Am Econ J: Microecon. 2011;3:139-164.

49. Cunningham AB. African Medicinal Plants setting priorities at the interface between conservation and primary health care. Working Paper 1. Paris: UNESCO; 1993.

50. Maffi L, Woodley E. Biocultural Conservation: A Global Sourcebook. London: Earthscan Ltd; 2010.

51. Melis AP, Semmann D. How is human cooperation different? Philos Trans R Soc Lond B Biol Sci. 2010; doi: doi.org/10.1098\%2Frstb.2010.0157.

52. Alexander RD. 1987. The biology of moral systems. New York: Walter de Gruyter; 1987.

53. Ladio AH, Albuquerque UP. The concept of hybridization and its contribution to urban ethnobiology. Ethnobio Conserv. 2014; doi: doi.org/10.15451/ec2014-11-3.6-1-9.

54. Nascimento ALB, Medeiros PM, Albuquerque UP. Factors in hybridization of local medical systems: Simultaneous use of medicinal plants and modern medicine in Northeast Brazil. PLOS ONE. 2018; doi: doi.org/10.1371/journal.pone.0206190.

55. Fabrega H. Evolution of sickness and healing. Berkeley: University of California Press; 1997.

\section{Figures}




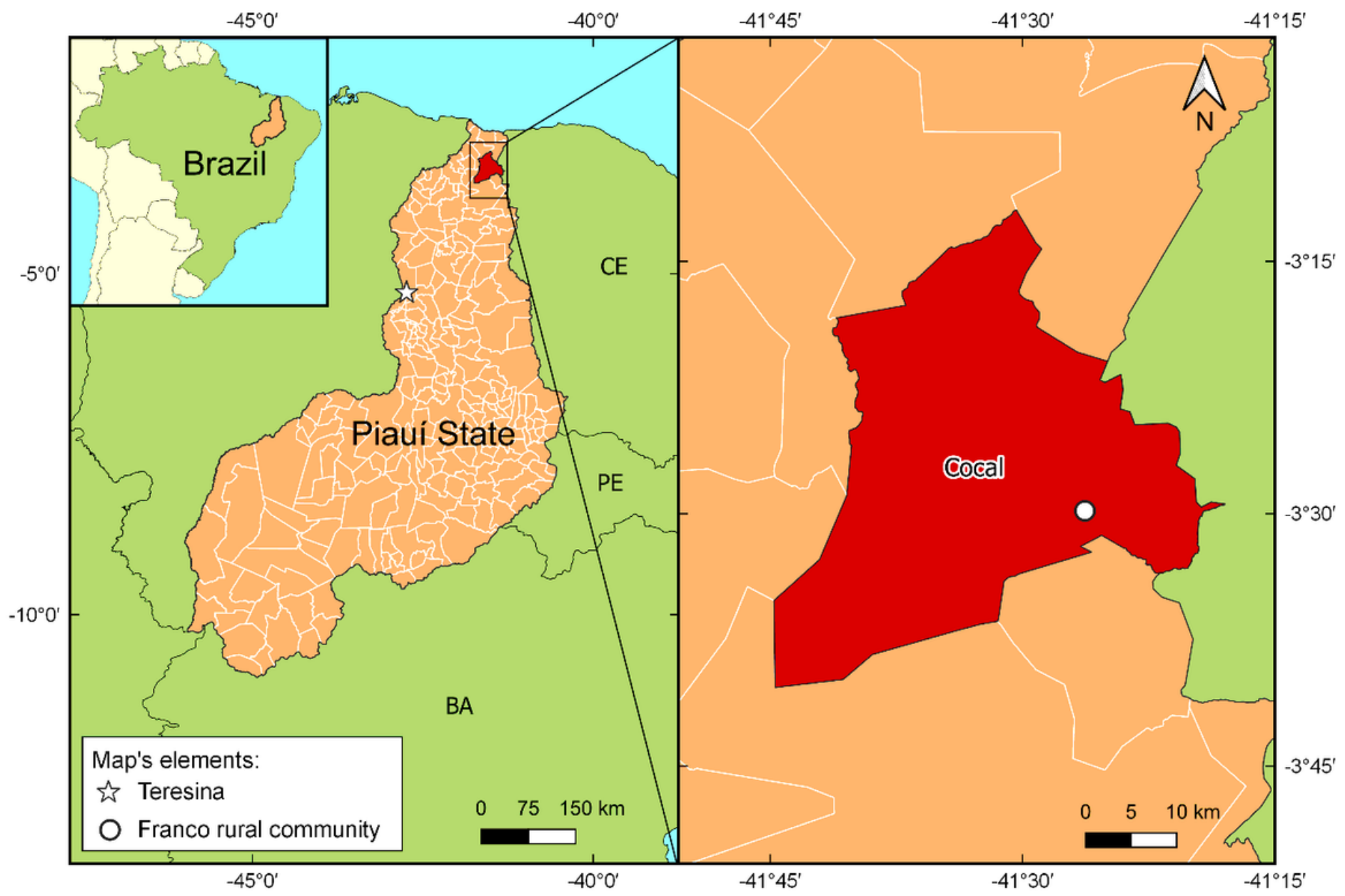

Figure 1

Location of Franco rural community, Cocal, northern Piauí state, Brazil. Adapted from IBGE (2010). Note: The designations employed and the presentation of the material on this map do not imply the expression of any opinion whatsoever on the part of Research Square concerning the legal status of any country, territory, city or area or of its authorities, or concerning the delimitation of its frontiers or boundaries. This map has been provided by the authors. 


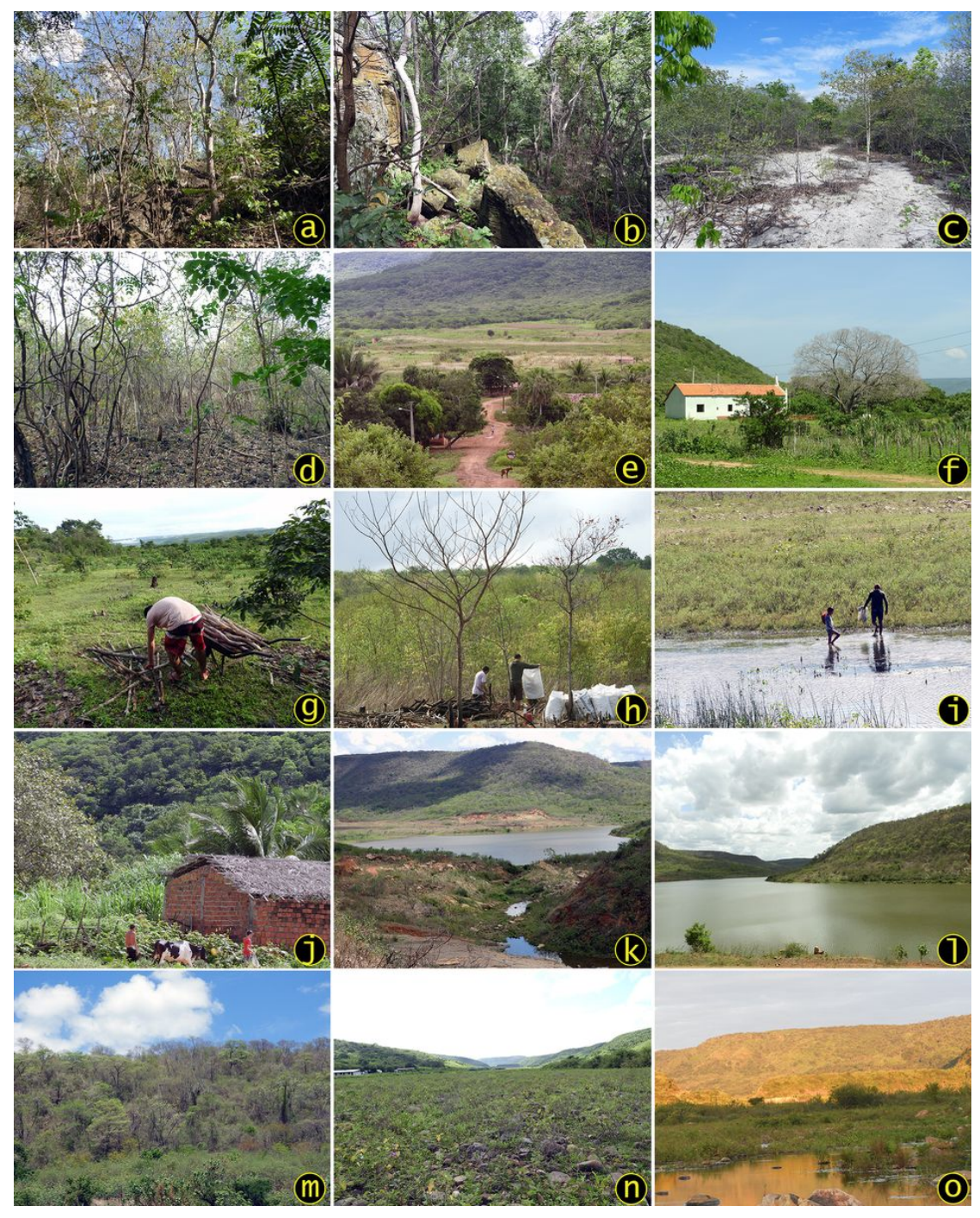

\section{Figure 2}

Landscapes and routines commonly observed in the Franco rural community: [a-d]. typical vegetation of the area; [e]. Lower part of the community in terms of relief; [f] Local Catholic Church; [g]. Young male collecting firewood; [h]. Men producing charcoal; [i]. Male adult and child fishing; [j]. Male adult and young adolescent taking a cow to the corral; [k-1]. Current areas of "Barragem Algodões I"; [m]. Vegetation phytophysiognomy in nearby areas to "Barragem Algodões I"; [n]. Portion of the Franco community area destroyed by the "Algodões" catastrophe (May 2009), where many people lived. In current times, there is the presence of many herbs, sub-shrubs and alien vegetal species; [o]. In the upper left corner, the destroyed wall of the "Barragem Algodões I" is observed. 


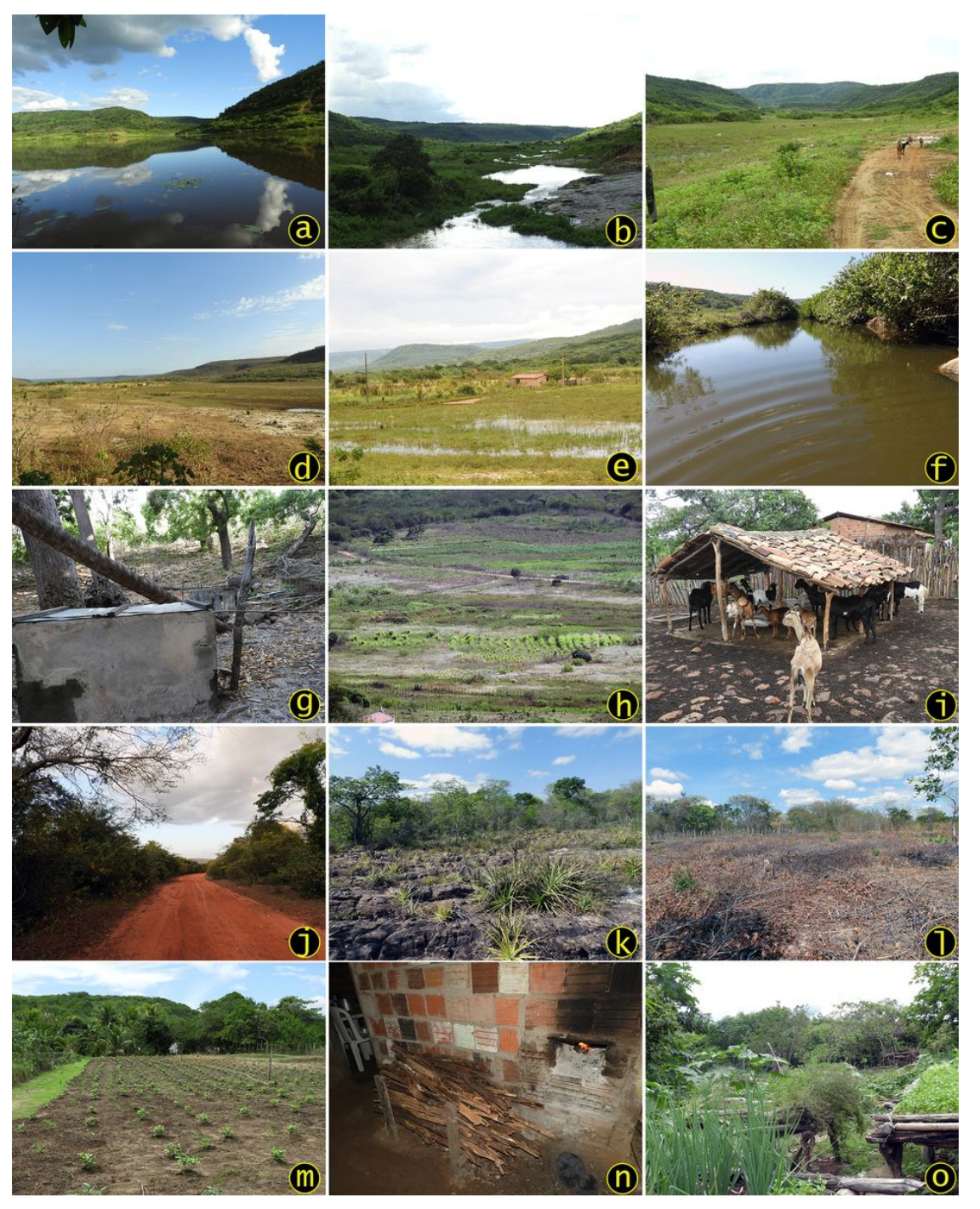

\section{Figure 3}

Landscapes and routines commonly observed in the Franco rural community: [a]. Current area of "Barragem Algodões I". [b]. In past times, many families lived in that area, which was totally destroyed by the "Algodões" catastrophe; [c] Road that gives access to the "Barragem Algodões I"; [d-e]. Portion of the Franco community area destroyed by the "Algodões" catastrophe; [f]. Portion of Piranji River, a place frequently used to wash clothes and for recreation; [g]. Reservoirs used by some residents to store water; [h]. Highly modified biocultural landscape, plants and cultivated crops are observed; [i]. Goat breeding is part of the local livestock; [j]. Road that gives access to the Franco rural community; [k]. Typical vegetation observed in rocky areas (popularly known as "lajeiros"); [l]. Forest felling for the formation of planting areas; [m]. Planting areas; [n]. Firewood used to prepare food; [o]. Some plants species cultivated in raised plant bed (present in homegardens). 


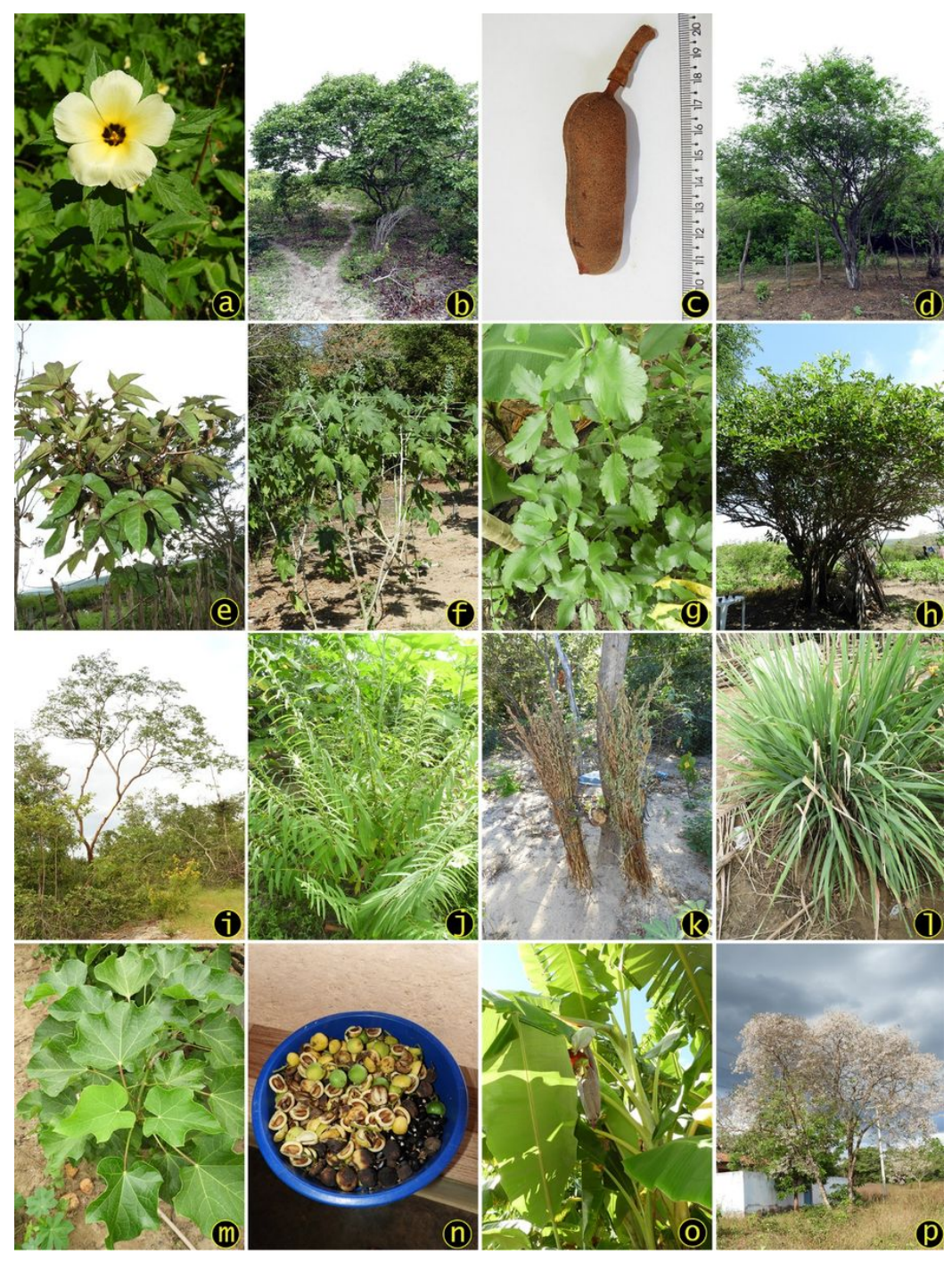

\section{Figure 4}

Some of the medicinal plant species commonly used in the Franco rural community: [a]. Turnera subulata Sm. (xanana); [b-c]. Hymenaea stigonocarpa Mart. ex Hayne (jataí); [d.] Libidibia ferrea (Mart. ex Tul.) L.P.Queiroz (jucá); [e]. Gossypium herbaceum L. (algodão-roxo); [f]. Ricinus communis L. (mamona); [g]. Bryophyllum pinnatum (Lam.) Oken (coraima); [h]. Tocoyena formosa (Cham. \& Schltdl.) K.Schum. (jenipapo, geniparana); [i]. Amburana cearensis (Allemão) A.C.Sm. (imburana-de-cheiro); [j-k]. Sesamum indicum L. (gergelim-preto); [l]. Cymbopogon citratus (DC.) Stapf (capim-santo); [m-n]. Jatropha curcas L. (pinhão-manso); [o]. Musa x paradisiaca L. (bananeira); [p]. Luetzelburgia auriculata (Allemão) Ducke (sucupira). Nomenclatural data has been updated from information available on [42] and [43]. 

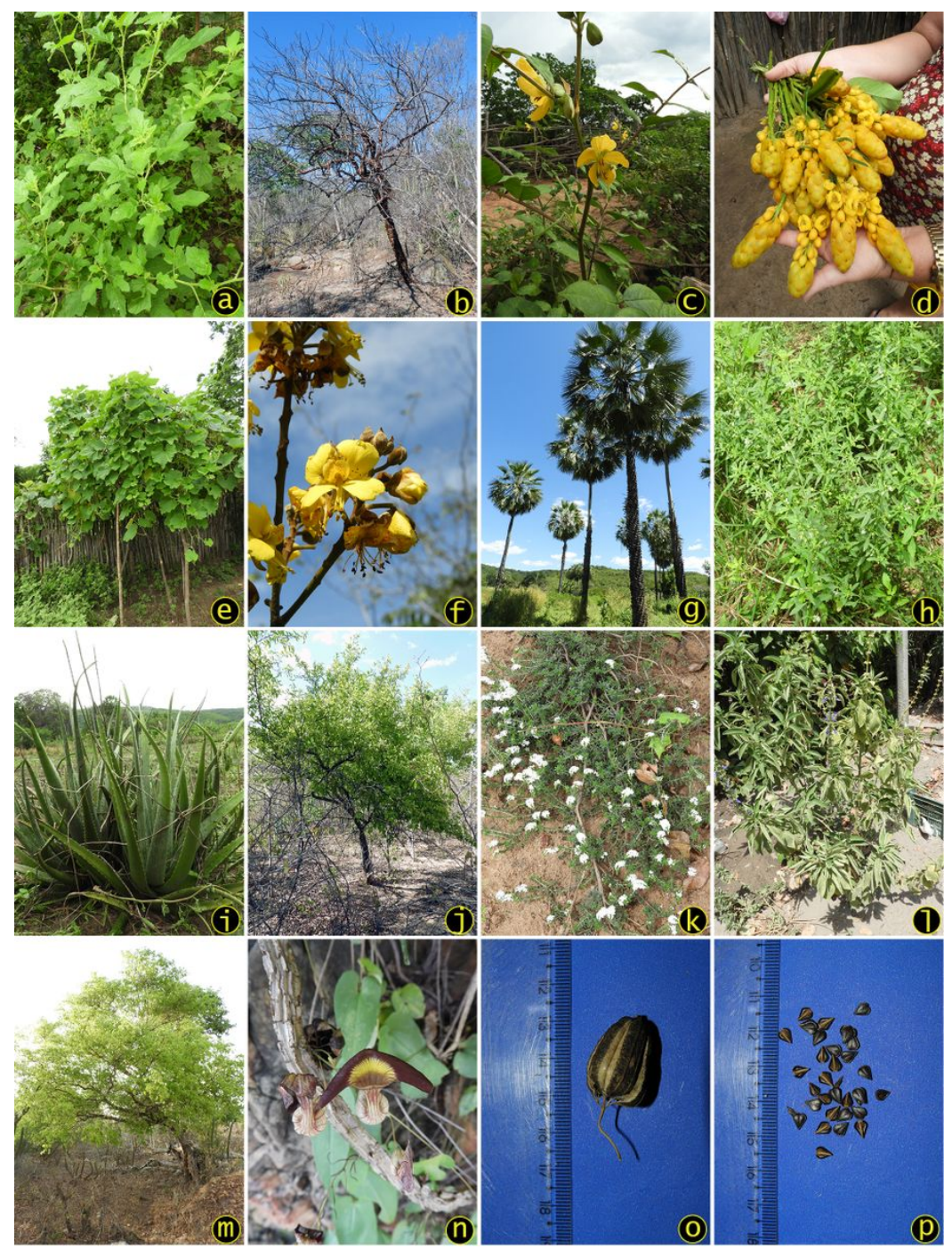

Figure 5

Some of the medicinal plant species commonly used in the Franco rural community: [a]. Solanum agrarium Sendtn. (melancia-da-praia); [b]. Commiphora leptophloeos (Mart.) J.B.Gillett (imburana-de-espinho); [c]. Senna occidentalis (L.) Link (manjerioba); [d]. Senna alata (L.) Roxb. (canafístula); [e]. Lagenaria vulgaris L. (cabaça); [f]. Cenostigma nordestinum Gagnon \& G.P.Lewis (catingueira); [g]. Copernicia prunifera (Mill.) H.E.Moore (carnaúba); [h]. Scoparia dulcis L. (vassourinha); [i]. Aloe vera (L.) Burm.f. (babosa); [j]. Ximenia americana L. (ameixa); [k]. Euploca polyphylla (Lehm.) J.I.M.Melo \& Semir (sete-sangrias); [l]. Plectranthus barbatus Andr. (boldo); [m]. Terminalia fagifolia Mart. (cascudo); [n-p]. Aristolochia birostris Duch. (cipó-de-jericó). Nomenclatural data has been updated from information available on [42] and [43]. 


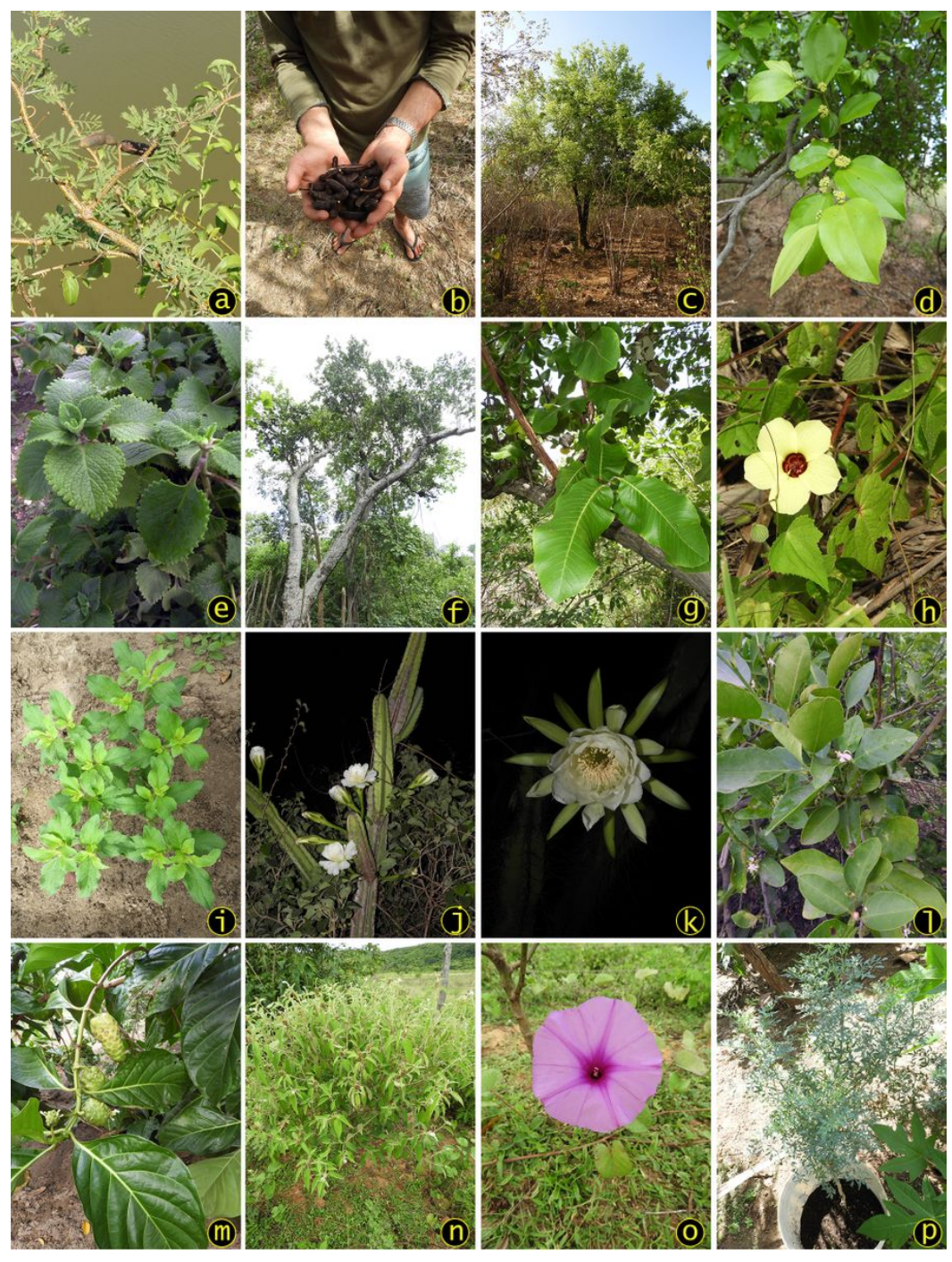

\section{Figure 6}

Some of the medicinal plant species commonly used in the Franco rural community: [a-b]. Vachellia farnesiana (L.) Wight \& Arn. (coronha); [c-d]. Sarcomphalus joazeiro (Mart.) Hauenshild (juazeiro); [e]. Plectranthus amboinicus (Lour.) Spreng. (malva-do-reino); [f-g]. Curatella americana L. (sambaíba); [h]. Pavonia cancellata (L.) Cav. (barva-de-veado); [i]. Acanthospermum hispidum DC. (cabeça-chata); [j-k]. Cereus jamacaru DC.

(mandacaru); [l]. Citrus x limon (L.) Osbeck (limão) [m]. Morinda citrifolia L. (noni); [n]. Croton sp. (velame); [o]. Ipomoea asarifolia (Desr.) Roem. \& Schult. (salsa); [p]. Ruta graveolens L. (arruda). Nomenclatural data has been updated from information available on [42] and [43]. 

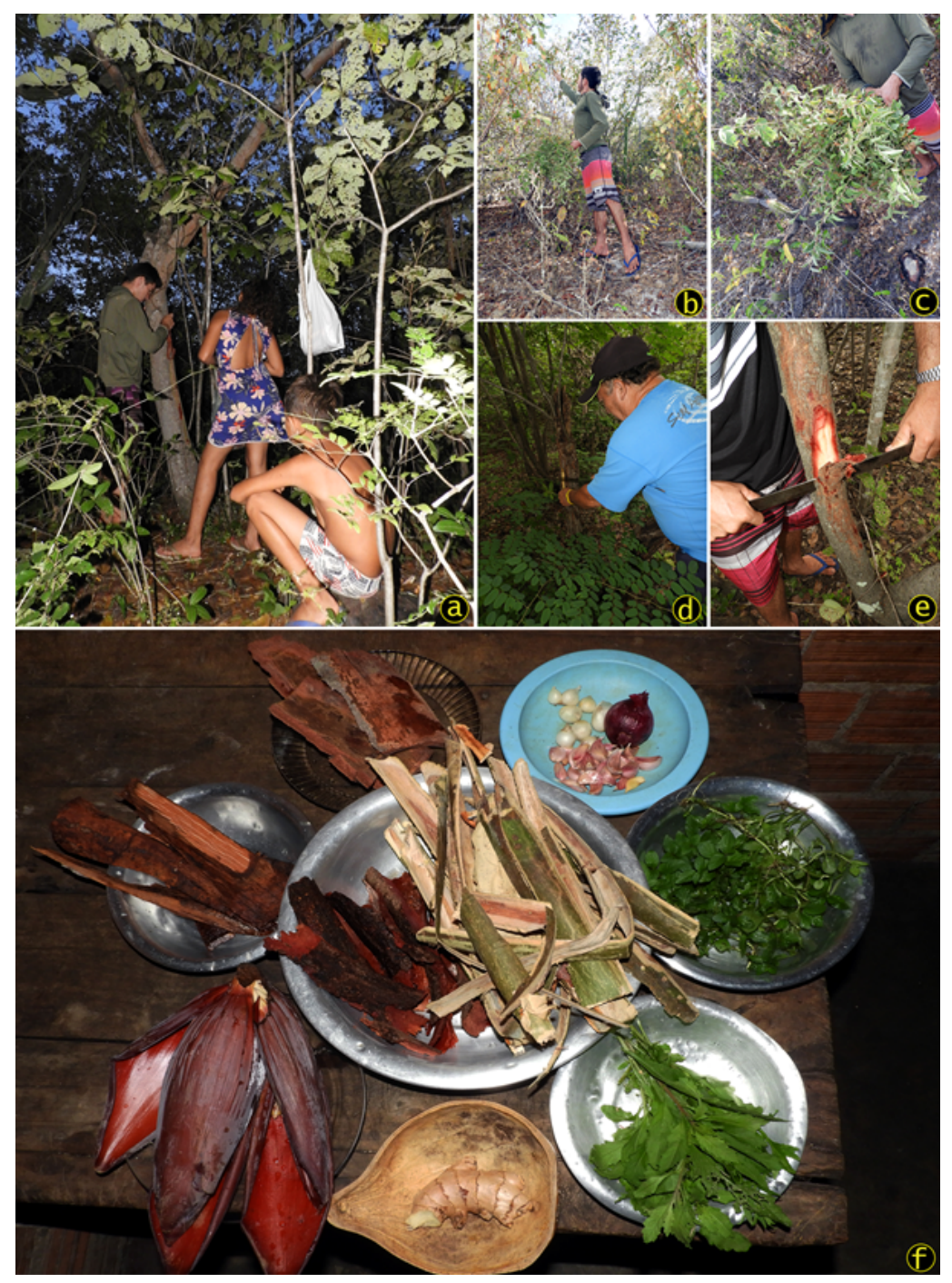

\section{Figure 7}

Local male residents harvesting medicinal plants in the forests of the Franco rural community: [a]. young adult collecting stem barks of Hymenaea sp. (jatobá) for medicinal use, children can accompany him and also learn these practices; [b-c]. local resident harvesting branches of Croton zehntneri Pax \& K.Hoffm. (canela-de-cunhã); [d]. adult harvesting stem barks of A. cearensis (imburana-de-cheiro), a rare medicinal species in the community; [e]. Harversting stem barks of $\mathrm{X}$. americana (ameixa) by local male resident; [f]. medicinal plants harvested and/or acquired by a male person for the preparation of a plant complex (syrup).. 


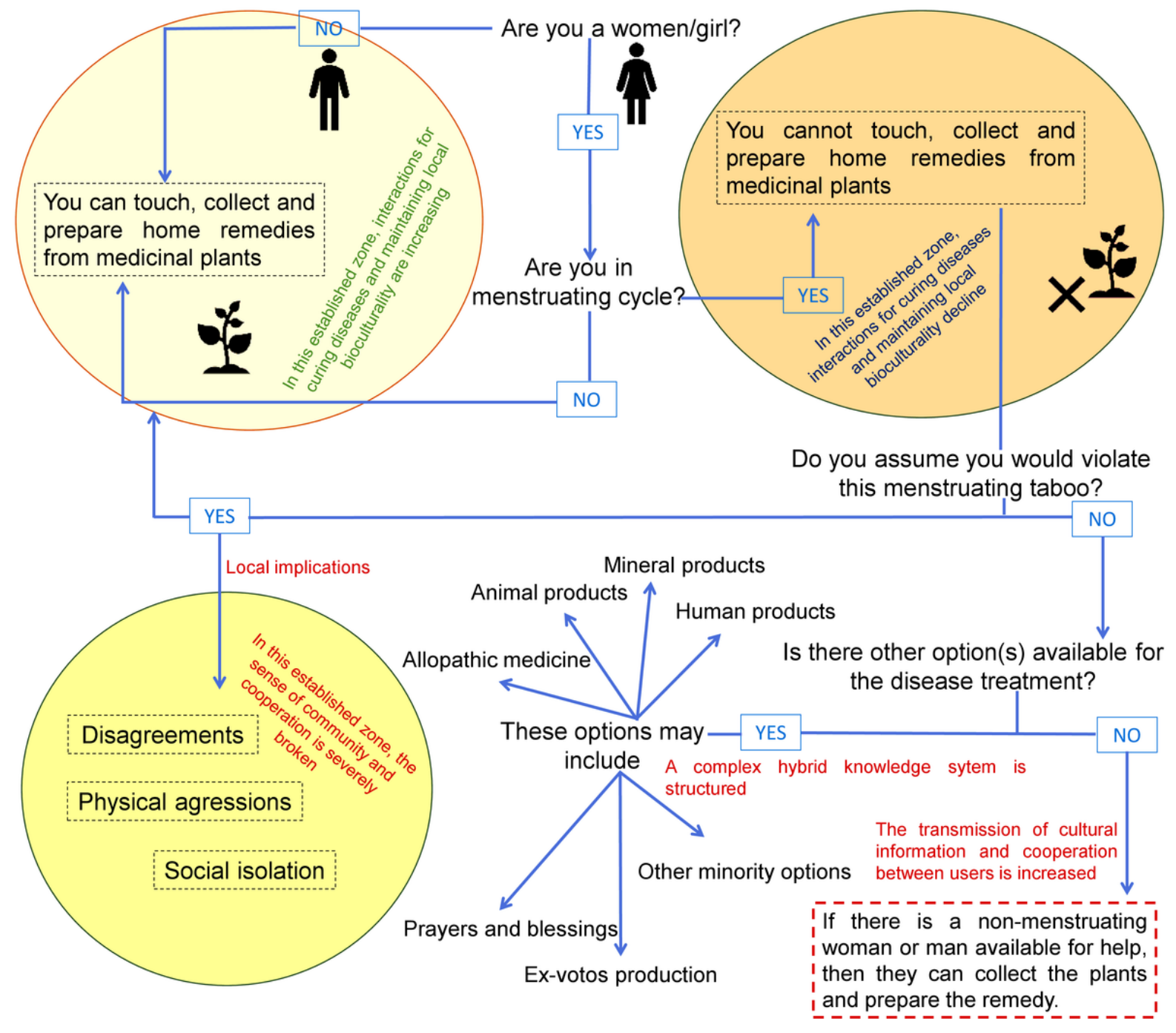

Figure 8

Representation of human behavior by men and women related to the structuring and/or establishing of the menstruating taboo described. Local implications of this taboo and some alternative options for disease treatment also are shown. 